\title{
Nilai-Nilai Pendidikan Islam Dalam Tradisi Sumbayang Ampek Puluah Hari Dalam Tarekat Syattariyah di Nagari Sintuak (Studi Etnografi)
}

\author{
Zilfadlia Nirmala1, Rengga Satria ${ }^{2}$ \\ zilfadilanirmala@gmail.com ${ }^{1}$, renggasatria@fis.unp.ac.id ${ }^{2}$ \\ Universitas Negeri Padang ${ }^{1,2}$
}

\begin{tabular}{l}
\hline ARTICLE INFO \\
\hline Article history: \\
Received 5 Agustus 2021 \\
Revised 24 Agustus 2021 \\
Accepted 31 Agustus \\
2021 \\
\hline
\end{tabular}

Keywords:

Tradisi sumbayang

ampek puluah hari,

Tarekat Syattariyah,

Nilai-nilai pendidikan

Islam

Clonflict of Interest:

None

\section{Funding:}

None

\begin{abstract}
Penelitian ini dilatarbelakangi oleh ketertarikkan terhadap tradisi sumbayang ampek puluah hari dalam tarekat Syattariyah. Penelitian ini bertujuan untuk menelaah: pertama, sejarah tradisi sumbayang ampek puluah hari. Kedua, pelaksanaan tradisi sumbayang ampek puluah hari. Ketiga, nilainilai pendidikan Islam dalam tradisi sumbayang ampek puluah hari. Metode yang digunakan dalam penelitian ini ialah penelitian kualitatif dengan pendekatan deskriptif serta menggunakan studi etnografi. Penelitian dilakukan di Nagari Sintuak. Pengumpulan data dilakukan dengan menggunakan metode wawancara, observasi, dan dokumentasi. Data yang diperoleh kemudian dianalisis dengan reduksi data, penyajian data, dan penarikan kesimpulan, setelah itu digunakan beberapa teknik untuk menguji keabsahan data di antaranya perpanjangan keikutsertaan, ketekunan pengamatan, dan triangulasi. Hasil penelitian menunjukkan bahwa: pertama, sejarah tradisi sumbayang ampek puluah hari dalam tarekat Syattariyah dimulai pada tahun 1111 Hijriyah. Kedua, adapun pelaksanaan tradisi sumbayang ampek puluah hari dilaksanakan seperti shalat berjama'ah pada umumnya serta ada penambahan shalat Qadha. Ketiga, nilai-nilai pendidikan Islam dalam tradisi sumbayang ampek puluah hari yaitu terdapat nilai spiritual,nilai integritas, nilai sosial serta nilai kedisiplinan
\end{abstract}


Zilfadlia Nirmala dan Rengga Satria: Nilai-Nilai Pendidikan Islam Dalam Tradisi Sumbayang Ampek...

\section{Pendahuluan}

Pengembangan Islam oleh ulama Nusantara secara umum menggunakan jalur tarekat, tak terkecuali dengan Syekh Abdur Rauf. Syekh Burhanuddin, selaku muridnya di pantai Barat Sumatera, juga menggunakan media tarekat dalam mengembangkan agama Islam. Tarekat yang dipilih oleh beliau adalah tarekat Syattariyah (Duski,2002:135). Salah satu tempat yang menganut tarekat Syattariyah adalah Kelurahan Simpang Tiga Sintuak, Kecamatan Sintuak Toboh Gadang, Kabupaten Padang Pariaman.

Di daerah ini ,tarekat Syattariyah dikembangkan di sebuah surau/mushalla. Munculnya tarekat sebagai metode dalam menanamkan pendidikan Islam bagi para pengikutnya sangatlah efektif. Pendidikan Islam mempunyai relasi yang kuat dengan tasawuf.Dimana pendidikan Islam mengantarkan pada pemahaman yang konprehensif menuju manusia seutuhnya sebagai hamba Allah SWT sedangkan tasawuf yakni penghambaan yang murni dengan kesucian hati. Tidak ada penghambaan yang murni tanpa pemahaman agama yang baik, dan belum dikatakan baik pemahaman keagamaan bila belum menghambakan diri dengan cara yang baik.

Kemudian pendidikan Islam, lebih menekankan kepada nilai-nilai Islam, dimana pendidikan Islam merupakan usaha dalam mengubah tingkah laku individu. Perubahan ini haruslah dilandasi dengan proses yang senantiasa berada dalam nilainilai Islami, yaitu nilai-nilai yang melahirkan norma-norma syari'ah dan akhlak alkarimah. (Muzayyin, 2012: 15) Bila pendidikan Islam dipandang sebagai suatu proses maka suatu proses tersebut akan berakhir pada tercapainya tujuan dari pendidikan. Suatu tujuan yang hendak dicapai oleh pendidikan pada hakikatnya adalah suatu perwujudan dari nilai-nilai pendidikan yang ideal yang terbentuk dalam pribadi manusia yang diinginkan. Berdasarkan permasalahan tersebut, maka akan di teliti mengenai nilai-nilai pendidikan Islam. Nilai pendidikan Islam merupakan kegiatan mendidik atau membimbing, serta mengarahkan dalam kaitannya dengan hal-hal yang bermanfaat untuk mencapai tujuan yaitu untuk perkembangan sesuai dengan syariat Islam.

Peneltian terkait tarekat Syattariyah di Kelurahan Simpang Tiga Sintuak dimulai ketika penulis melakukan observasi lapangan menegenai kajian tasawuf dan tarekat di daerah tersebut.Hal yang menarik perhatian yaitu kebiasaan atau tradisi dari tarekat Syattariyah.Tradisi yang dilakukannya ialah sebuah program wajib sekali setahun yaitu shalat selama empat puluh hari dengan cara berjamaah bersama-sama di mesjid/surau. Shalat selama empat puluh hari ini biasanya dilakukan sebelum masuknya bulan ramadhan.Shalat selama empat puluh hari ini, kebanyakan diikuti oleh kaum perempuan yang sudah menopause, karena dalam tradisi ini shalat yang dilaksanakan tidak boleh terputus.Maksud dari terputus disini adalah terhalang dalam melaksanakan shalat seperti dalam keadaan haid.

Berdasarkan fenomena tradisi yang dilaksanakan dalam tarekat Syattariyah di Nagari Sintuak ini, peneliti melihat bahwa adanya nilai-nilaipendidikan Islam yang terdapat di dalamnya. Seperti nilai kedisiplinan dimana dalam pelaksanaan tradisi sumbayang ampek puluah hari ini terdapat kedisiplinan waktu bagi jama'ah untuk datang kebih awal sebelum masuk waktu shalat.Kemudian nilai spiritual yang mencakup ibadah-ibadah yang didalakukan selama pelaksanaannya.Serta nilai sosial dan integritas yang tinggi.

Maka berangkat dari uraian di atas, penulis memandang perlu untuk mengadakan penelitian sebagai tugas akhir mengenai studi etnografi yang berjudul “ Nilai-Nilai Pendidikan Islam dalamTradisi Sumbayang Ampek Puluah Hari 
dalam Tarekat Syattariyah di NagariSintuak". Penulis disini akan membahas mengenai nilai-nilai pendidikan yang terdapat dalam tradisi tersebut.

Penelitian ini bertujuan untuk mendeskripsikan pelaksanaan serta nilai-nilai pendidikan dalam tradisi sumbayang ampek puluah hari dalam tarekat Syattariyah di Nagari Sintuak.

Perbedaan penelitian ini dengan penelitian sebelumnya yaitu penelitian Akmal Hadi(2014) dengan judul"Tradisi Sholat 40 Hari Berjama'ah (10 Terakhir Rajab Hingga 30 Sya'ban) Dalam Warga Desa Sipungguk Ditinjau Bagi Perspektif Hukum Islam" memiliki kaitan persamaan yang terletak pada subjek yang sama yakni tradisis shalat 40 hari berjama'ah, perbedaannya terletak pada hal yang akan diteliti.

\section{Tinjauan Pustaka}

\section{a. Nilai-Nilai Pendidikan Islam}

Nilai-nilai pendidikan Islam adalah seperangkat kepercayaan atau keyakinan yang ada di dalam diri manusia yang sesuai dengan norma ajaran Islam untuk menciptakan insan kamil atau manusia sempurna (Nugroho, 2017: 75). Nilai-nilai pendidikan Islam yaitu sifat-sifat atau halhal yang melekat pada pendidikan Islam yang digunakan sebagai dasar manusia untuk mencapai tujuan hidup manusia yaitu mengabdi kepada Allah SWT (Zein dkk, 2017: 61).

Dalam Al-Quran memuat nilai normatif yang menjadi sebuah patokan atau acuan dalam pencapaian pendidikan Islam. Nilai yang dimaksud disini adalah:

1) I"tiqadiyah, yaitu yang berkaitan dengan pendidikan iman, misalnya percaya kepada Allah SWT, percaya kepada malaikat, percaya kepada rasul, percaya pada kitab, percaya kepada hari akhir dan percaya kepada takdir. Pendidikan I"tiqadiyah ini bertujuan untuk menata kepercayaan pada setiap individu. Seperti terdapat dalam Q.S AlKahfi[17]:110, Q.S Az-Zumar[39]:65, Q.S An-Nahl[16]:36 dan dalil lainnya.

2) Khuluqiyah, hal ini berkaitan dengan pendidikan etika yang mempunyai tujuan membersihkan diri dari kegiatan atau perilaku yang tidak baik dan agar menerapkan perilaku terpuji atau mahmudah. Seperti terdapat dalam Q.S Al-Ahzab[33]:21, Q.S Al-Qalam[68]:9, Q.S An-Nahl[16]:4, Q.S An-Nisa[4]:65, dan dalil lainnya.

3) Amaliyah, yang berkaitan dengan pendidikan pada aktivitas seharihari, baik itu yang berkaitan dengan pendidikan ibadah ataupun pendidikan muamalah. Seperti terdapat dalam Q.S Al-A'raf[7]:59, Q.S AlA'raf[7]:65, Q.S Al-A'raf[7]:73, Q.S Al-A'raf[7]:85, Q.S Al-Baqarah[2]: 275 dan dalil lainnya.

\section{b. Tradisi Sumbayang Ampek Puluah Hari}

1) Tradisi

Tradisi berasal dari bahasa latintraditio yaitu suatu kebiasaan yang berkembang dimasyarakat yang menjadi adat kebiasaan (Ensiklopedi Hukum Islam: 2015). Secara termologi perkataan tradisi berisi suatu pengertian yang tersembunyi tentang adanya kaitan masa lalu dengan masa sekarang.Dia menunjuk kepada suatu yang diwariskan oleh masa lalu namun masih berwujud serta berperan pada 
Zilfadlia Nirmala dan Rengga Satria: Nilai-Nilai Pendidikan Islam Dalam Tradisi Sumbayang Ampek...

masa saat ini.Tradisi memperlihatkan bagaimana anggota masyarakat bertingkah laku, baik dalam kehidupan yang bersifat duniawi maupun terhadap hal yang gaib atau keagamaan.

2) Sumbayang Ampek Puluah Hari

Sumbayang 40 hari adalah istilah dari shalat berjama'ah yang dilaksanakan selama 40 hari tanpa terputus-putus. Pelaksanaannya pun sama seperti shalat fardhu berjama'ah pada umumnya.

\section{c. Tarekat Syattariyah}

Tarekat Syattariyh adalah aliran tarekat yang pertama kali muncul di India pada abad ke-15, tarekat ini di nisbatkan pada tokoh yang mempopulerkan dan berjasa mengembangkannya Abdullah asy Syattar. Di Sumatera Barat khususnya di Pariaman, ajaran ini dibawa oleh Syekh Burhanuddin.

Bukti tegas ajaran tarekat Syattariyah yang dibawa Syekh Burhanuddin di Sumatera Barat yaitu sampai sekarang tetap bertahan ajaran Islam tradisional yang mengakar pada sebagian besar masyarakat adalah tarekat Syattariyah dan sudah dianggap sebagai ajaran tarekat yang paling awal. Sebelum akhirnya tarekat Naqsabandiyah pada sekitar tahun 1850 (Oman Fathurrahman, 2008:43).

\section{Metodologi}

Metode yang dipakai dalam penelitian ini adalah penelitian kualitatif dengan menggunakan metode deskriptif. Penelitian yang dilakukan oleh penulis termasuk dalam kategori Studi Etnografi. Menurut Creswell (2012:462), studi etnografi adalah Ethnographic designs are qualitative research procedures for describing, analyzing,and interpreting a culture-sharing group's shared patterns of behavior, beliefs, and languagethat develop over time. Informan dalam penelitian ini ialah pimpinan surau sekaligus guru tarekat Syattariyah dan para jama'ah tradisi sumbayang ampek puluah hari. Pengumpulan data yang diperlukan penelitian ini menggunakan teknik observasi,wawancara, dan dokumentasi. Setelah data dikupulkan data tersebut dianalisis secara kualitatif dengan model Miles and Huberman. Menurut Miles dan Huberman (Sugiyono,2007), aktivitas dalam analisiss data kualitatif dilakukan secara interaktif dan terus menerus sampai tuntans yang digambarkan dalam empat langkah. Empat langkah tersebut meliputi data collecting (pengumpulan data), data reduction (reduksi data), data display (penyajian data), dan conclusion drawing/verification (penarikan kesimpulan dan verifikasi). Ketepatan dan kebenaran data yang sudah berhasil digali, dikumpulkan dan dicatat dalam kegiatan penelitian harus dipastikan dengan baik. Untuk menguji kredibilitas dan pengecekan data, maka diperlukan teknik pemeriksaan. Terdapat beberapa teknik yang digunakan dalam pengecekan keabsahan temuan di antaranya yaitu perpanjangan keikutsertaan,ketekunan pengamamatan, dan triangulasi.

\section{Hasil dan Pembahasan}

\section{a. Sejarah Tradisi Sumbyang Ampek Puluah Hari Dalam Tarekat Syattariyah}

Berdasarkan hasil wawancara yang dilaksanakan pada hari selasa tanggal 22 Juni 2021 bersama Syekh Buya Azwar Tk Sidi bahwasannya 
sumbayang ampek puluah hari hanya ada pada tarekat Syattariyah. Terbentuknya tradisi ini dipelopori oleh Syekh Buya Tanjung Medan yang menganut tarekat Syattariyah dari Syekh Burhanuddin.Menurut Syekh Buya Azwar Tk. Sidi awal munculnya sumbayang ampek puluah hari semenjak tahun 1111 Hijriyah. Hal ini berlandaskan hadist Nabi Muhammad SAW mengenai seruan untuk shalat berjamaah selama 40 hari, menurut Syekh Buya Azwar Tk Sidi hadistnya berbunyi : "Siapo sumbayang ampek puluahhari, baimam-imaman, mandapek takbir samo jo imam, indak lupuik satu raka'at pun bajama'ah salamo ampek puluah hari dari mulai takbiratul ihram sampai salam salamo ampek puluah hari, itu lapeh dari duo puluah duo jalan , talapeh dari syirik dan munafik".(Wawancara, 22 Juni 2021)

. Hal tersebut dijelaskan dalam sebuah hadis riwayat Tirmidzi yang berbunyi:

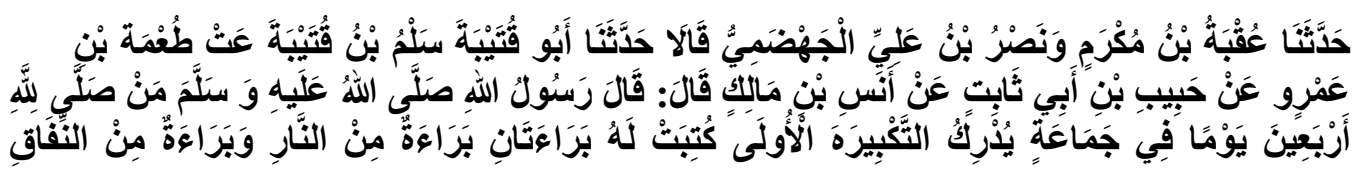

"Telah menceritakan kepada kami Uqbah bin Mukram dan Nashr bin Ali Al Jahdlami keduanya berkata: telah menceritakan kepada kami Abu Qutaibah Salm bin Qutaibah dari Thu'mah bin 'Amru dari Habib bin Abu Tsabit dari Anas bin Malik ia berkata: "Rasulullah shalallahu 'alaihi wasallam bersabda:"Barangsiapa shalat berjama'ah selama empat puluh hari dengan mendapatkan takbir pertama ikhlas karena Allah, maka akan dicatat baginya terbebas dari dua hal: terbebas dari api neraka dan terbebas dari sifat munafik."(Abu Isa Muhammad, 1975:206)

\section{b. Pelaksanaan Tradisi Sumbayang Ampek Puluah Hari Dalam Tarekat Syattariyah}

Berdasarkan hasil wawancara dan observasi peneliti dalam pelaksanaan tradisi sumbayang ampek puluah hari tepatnya di Surau Tk. Sidi , penulis menemukan bahwa pelaksanaan sumbayang ampek puluah hari yang dilaksanakan secara berjama'ah selama 40 hari dimulai pada 20 hari terakhir bulan Rajab sampai 20 hari bulan Sya'ban. Pada proses pelaksanaan tradisi ini di mulai pada hari Jum'at pada waktu sholat dzuhur, kemudian dilanjutkan dengan "mambukak kaji" sehabis shalat Isya , dan para jama'ah membawa "nasi bajamba" untuk di santap bersama.Hal ini dikuatkan dengan hasil wawancara bersama pemilik surau sekaligus imam dalam pelaksanaan tradisi sumbayang ampek puluah hari yaituk Buya Azwar Tk. Sidi, beliau mengatakan bahwa: "Sumbayang ampek puluh hari pada awal pelaksanaanya dimulai dengan membuka kaji/ mendoa bersama, pertama doakan semoga badan sehat, kemudian di bacakan doa untuk mauled nabi, ketika mau "sumbayang" kita niatkan mudah-mudahan kita beribadah selama 40 hari tanpa terputusputus, kemudian baca Al-Fatihah."(Wawancara , 22 Juni 2021)

Kemudian pada proses pelaksanaannya seperti sholat berjamaah pada umumnya. Namun sehabis melaksanakan sholat wajib berjamaah, ada penambahan shalat yaitu shalat Qadha atau disebut juga shalat pengganti yang dilaksanakan secara berjamaah juga.shalat Qadha dilakukan yang bertujuan untuk mengganti shalat wajib yang pernah tinggal semasa hidup. 
Zilfadlia Nirmala dan Rengga Satria: Nilai-Nilai Pendidikan Islam Dalam Tradisi Sumbayang Ampek...

Hal ini diperkuat dengan hasil wawancara bersama Buya Azwar Tk. Sidi, beliau mengatakan bahwa: "Sumbayang Qadha atau shalat pengganti, bertujuan untuk mengganti sholat yang tinggal selama hidup di dunia, hal ini lebih di khususkan kepada wanita dikarena wanita mendapatkan larangan sholat ketika haidh, kemudian ketika sudah selesai halangan pada waktu dzuhur tetapi dia mandi wajib pada waktu ashar, jadi tertinggallah sholat dzuhur, jadi sholat dzuhur yang tertinggal ini yang diganti". (Wawancara, 22 Juni 2021)

Menurut Ahmad Sarwat (2018) kata qadha, secara bahasa berarti memutuskan atau mengganti, lalu secara istilah adalah mengerjakan shalat diluar waktu yang telah disyariatkan. Qadha shalat adalah melaksanakan shalat setelah batas waktu yang telah ditetapkan dan boleh dikerjakan dengan kondisi tertentu.Pada dasarnya mengqadha atau mengganti shalat yang terlewat merupakan ibadah yang disyariatkan dan bahkan diperintahkan di dalam syariat Islam. Hal ini dikuatkan oleh sebuah hadist yang diriwayatkan oleh Abu Hirairah radhiallahuanhu sebagai berikut:

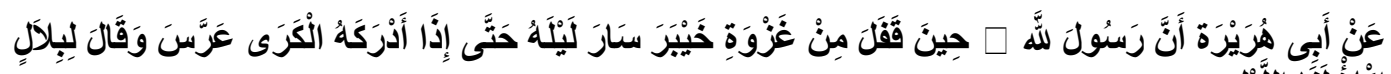

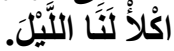

Dari Abi Huraurah radhiallahuanhu berkata," Ketika Rasulullah SAW kembali dari perang Khaibar, beliau berjalan di tengah malam hingga ketika rasa kantuk menyerang beliau, maka beliau pun berhenti untuk istirahat (tidur). Namun beliau berpesan kepada Bilal,"Bangunkan kami bila waktu shubuh tiba".

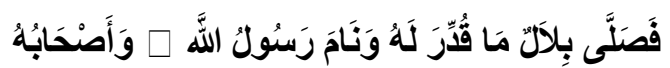

Sementara itu Bilal shalat seberapa dapat dilakukannya, sedang Nabi dan para sahabat yang lain tidur.

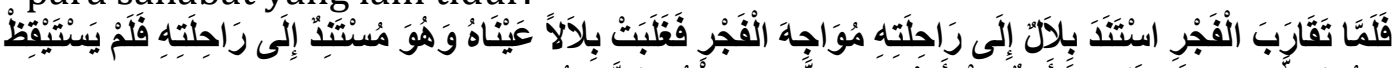

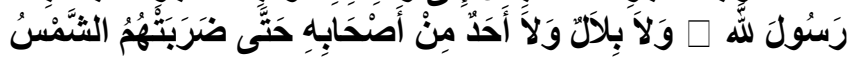

Ketika fajar hamper terbit, Bilal bersandar pada kendaraanya sambil menunggu terbitnya fajar. Namun rasa kantuk mengalahkan Bilal yang bersandar kepada untanya. Maka Rasulullah SAW, Bilal dan para sahabat tidak satupun dari mereka yang terbangun, hingga sinar mataharimenegnai mereka.

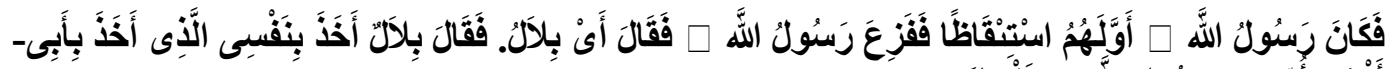

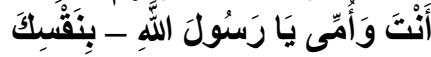

Yang mula-mula terbangun adala Rasulullah SAW. Ketika terbangun , beliau berkata, "Mana Bilal”. Bilal menjawab,"Demi Allah, Aku tertidur ya Rasulullh"

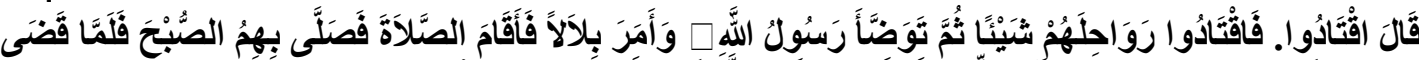

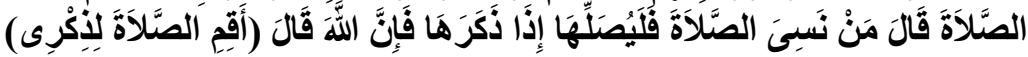

Beliau bersabda, “ Bersiaplah". Lalu mereka menyeiapkan kendaraan mereka. Lalu Rasulullah SAW Berwudhu' dan memerintahkan Bilal melantunkan iqamah dan Nabi SAW mengimami shalat Shubuh. Selesainya, beliau bersabda,"Siapa yang lupa shalat maka dia harus melakukannya 
begitu ingat. Sesungguhnya Allah berfirman," Tegakkanlah shalat untuk menginatpKu.(HR.Muslim)

Al-Imam An-Nawawi ketika menjelaskan hadits ini di dalam kitab Syarah Shahih Muslim menegaskan bahwa hadits ini menjadi dalil atas wajibnya mengqadha atau engganti shalat yang terkewat. Dan tidak ada bedanya, apakah shalat itu ditinggalkan karena adanya 'udzur syar'I seperti tertidur dan terlupa, atau pun ditinggalkan shalat itu tanpa 'udzur syar'I, seperti karena malas dan lalai.

\section{c. Nilai-Nilai Pendidikan Islam Dalam Tradisi Sumbayang Ampek Puluah Hari}

\section{1) Nilai Spiritual}

Salah satu nilai pendidikan Islam yang ditemukan adalah nilai spiritual. Berdasarkan hasil wawancara dengan Buya Azwar Tk Sidi selaku pmpinan sekaligus iman dalam pelaksanaan tradisi sumbayang ampek puluah,beliau mengungkapkan bahwa: "Dalam pelaksanaan sumbayang ampek puluah hari kita mendapatkan paket lengkap, maksudnya yaitu dari mulai sholat sunnat lengkap, sholat tepat waktu sampai dengan dzikir dan doanya. Sehingga kita mendapatkan ketenangan hati tanpa khawatir dengan persoalan dunia, karena yakin semua telah diatur oleh Allah sehingga kita hanya perlu berikhtiar dan istiqomah kepada Sang Pencipta”. (Wawancara, 22 Juni 2021)

Hal ini dikuatkan dengan hasil wawancara salah seorang jamaah yang biasa dipanggil Nenek Ani, beliau mengatakan bahwa: "Selama mengikuti tradisi ini yang sudah lebih dari enam kali, merasakan perubahan yang sangat besar terutama mendapatkan ketenangan dalam jiwa sehingga tidak merasakan penyakit hati". (Wawancara, 04 April 2021)

Nilai spiritual merupakan nilai tertinggi dan bersifat mutlak, karena bersumber dari sang pencipta yang dianggap sebagai kendali dalam memilih kehidupan yang baik atau buruk. Nilai spiritual mencangkup segala sesuatu yang berguna bagi rohani (Machmud,2015:3). Berdasarkan nilai-nilai pendidikan islam, nilai spiritual yang terdapat dalam tradisi sumbayang ampek puluah hari yaitu seiring dalam proses pelaksanaan sholat berjamaah yang dilakukan dengan benar-benar melakukan kekhusyukan mendapati ketenangan dalam hati, jauh dari perasaan takut serta was-was dalam menjalani kehidupan didunia. Menambah keyakinan akan keberadaan Allah sebagai sang pencipta, bahwa Allah satu-satunya tempat meminta pertolongan bagi hambanya dalam menghadapi setiap kesulitan yang ada. Hal ini sesuai dengan teori hikmah shalat berjama'ah Labib Mz-Harniawati (2006:257) salah satu hikmahnya yaitu mencegah manusia dari perbuatan jahat. Orang yang selalu mendirikan shalat hatinya bersih (jernih) jauh dari kotoran-kotoran dosa serta segala perilkunya selalu memancarkan cahaya ilahi.

2) Nilai Integritas

Integritas adalah konsistensi dan keteguhan yang tak tergoyahkan dalam menjujung tinggi nilai-nuilai keyakinan dan 
prinsip. Pada etika integritas bisa diartikan sebgai kebenaran dan kejujuranperbuatan seseorang. Berdasarkan hasil penelitian tradisi sumbayang ampek puluah hari, nilai integritas yang ada adalah dapat dilihat dari para jamaah yang berhasil menuntaskan tradisi ini dari awal hingga akhir, serta menumbuhkan semangat ingin mengikuti tradisi ini untuk tahun selanjutnya.

Berdasarkan hasil wawancara dan observasi dalam tradisi sumbayang ampek puluah hari juga terdapat nilai integritas. Sebagaimana yang dikatakan dalam wawancara bersama Buya Azwar Tk Sidi beliau mengatakan bahwa: "Dalam pelaksanaan tradisi ini dibutuhkan pendidirian yang teguh dalam pelaksaaanannya bahwa kita harus berkomitmen melaksanakan tradidi ini sampai selesai tanpa terputusputus". (Wawancara 22 Juni 2021)

Hal ini juga dinyatakan oleh Nenek Ani selaku salah satu jama'ah sumbayang ampek puluah hari, beliau mengatakan bahwa: "Dalam sumbayang ampek puluah dilaksanakan tanpa terputus-putus mengikuti takbirrratulihram imam". ( Wawancara, 04 April 2021)

\section{3) Nilai Sosial}

Nilai pendidikan Islam lainnya yang terdapat adalah nilai sosial,hal ini dapat dilihat dari hasil wawancara bersama Ama Ida sealku jam'ah yang telah mengikuti tradisi ini empat kali. Beliau mengatakan bahwa: "Selain mendapatkan ketenangan jiwa, serta tidak lupa juga rasa senang bertemu dengan teman-teman yang memang jarang bisa bertemu, jadi di tradisi ini menjadikan momen untuk bersilaturrahmi juga, ketika tradisi ini mau berakhir rasanya ingin terus tetap berlanjut". (Wawancara, 04 April 2021)

Selanjutnya pendapat lain datang dari Amak Simar, mengatakan bahwa: " Alasan ia mengikuti tradisi ini untuk pertama ialah karena beratnya masalah kehidupan rumah tangga, hingga memutuskan mengikuti sumbayang ampek puluah hari dan alhamdulillah mendapatkan ketenangan hati. Para jama'ah yang lebih tua juga memberikan nasehat yang baik terhadap masalah yang sedang ia hadapi".(Wawancara, 04 April 2021)

Menurut Kamus Besar Bahasa Indonesia (2004:1085) kata sosial diartikan "berkenaan dengan masyarakat atau suka memperhatikan kepentingan umum(suka menolong, menderma,dsb.). Kemudian menurut Jusnimar Umar dalam artikelnya yang berjudul "Perananan Nilai Sosial Dalam Pengembangan Pendidikan Umum" mengatakan bahwa nilai sosial adalah sesuatu yang berharga (berguna/bermanfaat) yang berhubungan dengan hubungan antarmanusia, dan menekankan pada segi kemanusiaan yang luhur serta menunjukkan perilaku yang dasarnya rela berkorban. Hal ini juga dapat dilihat dalam proses pelaksanaan tradisi sumbayang ampek puluah hari, jelas terlihat eratnya hubungan antar para jama'ah yakni saling berbagi dalam berbagai hal salah satunya dalam hal makanan serta berbagi pengalaman hidup, saling membantu atau member solusi terhadap jamaah yang mempunyai masalah dalam keluarganya.

\section{4) Nilai Kedisiplinan}


Kedisiplinan menurut Hani (2008:17), merupakan suatu hal yang sangat mutlak dalam diri kehidupan manusia, karena seorangf manusia tanpa disiplin yang kuat akan merusak sendi-sendi kehidupannya yang akan membahayakan dirinya dan manusia lainnya, bahkan alam sekitarnya. Dari hal ini dapat dilihat bahwa kedisiplinan sangatlah penting dalam kehidupan manusia.

Dari hasil wawancara dengan pemilik surau sekaligus guru yang membawa ajaran tarekat Syattariyah, beliau mengatakan bahwa : "Sumbayang ampek puluah hari mengajarkan kita membiasakan diri menjaga sholat tepat waktu". (Wawancara, 22 Juni 2021)

Pendapat yang sama datang dari Mami Eti, beliau mengatakan bahwa: "Kemudian setelah berakhirnya sholat berjama'ah selama 40 hari jadi terlatih sholat tepat waktu". (Wawancara, 04 April 2021)

Hal ini dikuatkan juga dengan pendapat Buk Ellia, beliau mengatakan bahwa: "Selama mengikuti tradisi sumbayang ampek puluah hari, kita terlatih untuk shalat tepat waktu, bahkan shalat sunnat rawatib pun yterlaksana juga, serta kebiasaan yang dilakukan selama empat puluh hari tersebut terbawa setelah tradisi ini berakhir".(Wawancara, 04 April 2021)

Berdasarkan hasil penelitian tradisi sumbayang ampek puluah hari , nilai keidisplinan yang terdapat didalamnya adalah kedisiplinan dalam segi waktu beribadah terkhususnya shalat wajib 5 waktu yaitu Shalat Shubuh, Dzuhur, Ashar, Maghrib dan Isya. Selama mengikuti tradisi selama 40 hari ini melatih kedisiplinan para jama'ah dalammelaksanakan sholat awal waktu, ketika tidak tepat waktu akan merasaseperti belum sholat atau lupa sudah melaksanakan sholat apa belum.

\section{Simpulan}

Pelaksanaan tradisi sumbayang ampek puluah hari dilaksanakan pada secara berjama'ah selama 40 hari dimulai pada 20 hari terakhir bulan Rajab sampai 20 hari bulan Sya'ban. Dimulai dengan niat awal untuk melaksanakan tradisi hingga tuntas, hingga pelaksanaan shalat berjama'ah lima waktu dengan penambahan shalat Qadha pada setiap shalat fardhu. Nilai-nilai pendidikan Islam yang terdapat dalam tradisi sumbayang ampek puluah hari adalah pertama, nilai spiritual yang meliputi ketenangan jiwa dan ketentraman hati serta dapat mengontrol emosi, kedua, nilai integritas yang meliputi komitmen dalam pelaksanaan tradisi ini dari awal hingga selesai, ketiga, nilai sosial yang meliputi terjalin kembali silaturrahim bersama teman yang jarang bertemu/ mempererat hablumminannas, keempat, nilai kedisiplinan yang meliputi kedisiplinan ketepatan waktu dalam mengerjakan shalat fardhu.

\section{Referensi}

Arifin, Muzayyin. 2012. Filsafat Pendidikan Islam. Jakarta: PT. Bumi Aksara.

Fathurahman, Oman. 2041. Tarekat Syattariyah di Minangkabau. Jakarta : Prenada Media Grup.

Handoko,T.Hani.2008. Manajemen.Yogyakarta: BPFE 
Zilfadlia Nirmala dan Rengga Satria: Nilai-Nilai Pendidikan Islam Dalam Tradisi Sumbayang Ampek...

Isa bin Saurah, Abu Isa Muhammad. 1975. Sunan at-Tirmidzi,Vol.1. Mesir Syirkah Maktabah.

Machmud, Surachmin.2015. Analisis Nilai Spiritual Dalam Novel Haji Backpacker Karya Aguk Irawan MN. Jurnal Humanika No.15,Vol.3.

Nugroho, Bekti Taufiq Ari. 2017. Identitas Nilai-nilai Pendidikan Islam Dalam Pemberdayaan Masyarakat Pada PNPM Mandiri.Jurnal Penelitian Vol. 11, No.1.

Samad, Duski. 2002. Syekh Burhanuddin dan Islmisasi Minangkabau Syarak Mandaki Adat Manurun. Jakarta : The Minangkabau Foundation.

Sarwat, Ahmad. 2048. Qadha Shalat Yang Terlewat Haruskah?. Jakarta: Rumah Fiqih Indonesia.

Sugiyono, (2046).Metode Penelitian Pendidikan Pendekatan Kuantitatif, kualitatif, dan $R \& D$, Bandung: Alfabeta.

Wawancara dengan Nenek Ani pada Tanggal 04 April 2021

Wawancara dengan Ama Ida pada Tanggal 04 April 2021

Wawancara dengan Mami Eti pada Tanggal 04 April 2021

Wawancara dengan Ibuk Ellia pada Tanggal 04 April 2021

Wawancara dengan Buya Azwar Tk Sidi pada Tanggal 22 Juni 2021 